\title{
BAGAIMANA REMAJA PANTI ASUHAN MEMANDANG MASA DEPAN? PENTINGNYA DUKUNGAN LINGKUNGAN
}

\author{
HOW ORPHANAGE ADOLESCENTS SEE THEIR FUTURE? THE \\ IMPORTANCE OF SOCIAL SUPPORT
}

\author{
Oleh: \\ Edgart Andrean ${ }^{1}$ \\ Sari Zakiah Akmal ${ }^{2}$
}

\begin{abstract}
ABSTRAK
Orientasi masa depan dapat menjadi faktor pelindung bagi remaja, terutama remaja panti asuhan yang hidup dengan kesulitan ekonomi dan berada dalam anggota kelompok minoritas. Pada masa remaja domain inti dari orientasi masa depan yang menjadi perhatian utama ialah terkait pendidikan dan pekerjaan. Pembentukan orientasi masa depan dapat dipengaruhi oleh berbagai faktor eksternal atau kontekstual atau yang disebut sebagai contextual support and barrier. Penelitian ini dilakukan untuk mengetahui peranan dari contextual support and barrier terhadap orientasi masa depan terkait pendidikan dan pekerjaan pada remaja panti asuhan di Jakarta dan Bekasi. Penelitian ini merupakan penelitian kuantitatif dengan jumlah subjek sebanyak 105 remaja yang tinggal di panti asuhan, yang diperoleh dengan teknik incidental sampling. Pengukuran orientasi masa depan menggunakan alat ukur Future Expectation Scale for Adolescents (FESA) dan pengukuran contextual support and barrier menggunakan alat ukur Contextual Support and Barrier. Hasil penelitian menunjukan bahwa contextual support berperan sebesar 8,7\% terhadap orientasi masa depan terkait pendidikan dan pekerjaan pada remaja panti asuhan. Oleh karena itu, dapat dikatakan bahwa ketika remaja panti asuhan merasa didukung oleh lingkungan (faktor kontekstual) dapat membantu mereka membentuk orientasi masa depan terkait pendidikan dan pekerjaan yang positif. Hasil ini diharapkan dapat menjadi acuan bagi pihak panti dan pemerintah dalam membuat program-program yang dapat membantu remaja panti mendapatkan dukungan dan membentuk orientasi masa depan yang positif.
\end{abstract}

Kata Kunci: Orientasi Masa Depan; Contextual Support dan Barrier; Remaja Panti Asuhan

\begin{abstract}
Future orientation can be a protective factor for teenagers, especially orphanage adolescents who live with economic difficulties and are in members of minority groups. In adolescence the core domain of the future orientation which the major concern is related to education and occupation. The formation of future orientation can be influenced by various external or contextual factors or stated as contextual support and barrier. This research was conducted to find out the role of contextual support and barrier to the future orientation related to education and work in the orphanage adolescence in Jakarta and Bekasi. This study is an associative study with a total of 105 adolescents living in an orphanage, obtained by incidental sampling technique. This study uses adaptation of Future Expectation Scale for Adolescents (FESA) and Contextual Support and Barrier measuring instruments. The results of research showed that contextual support contributed 8,7\% to the future orientation related to education and occupation on the orphanage adolescence. Therefore, it can be said that when the
\end{abstract}

\footnotetext{
${ }^{1}$ Fakultas Psikologi, Universitas YARSI, edgartandrean@ gmail.com

${ }^{2}$ Fakultas Psikologi, Universitas YARSI, sari.zakiah@gmail.com 
EDGART ANDREAN \& SARI ZAKIAH AKMAL, Bagaimana Remaja Panti Asuhan Memandang Masa Depan? Pentingnya Dukungan Lingkungan

orphanage adolescence feel supported by the environment (contextual factors) it can help them form a future orientation related to positive education and occupation. This result is expected to be a reference for the orphanage and the government in making programs that can help orphanage adolescent to get support and form a positive future orientation.

Keywords: Future Orientation; Contextual Support and Barrier; Orphanage Adolescents

\section{PENDAHULUAN}

Masa remaja merupakan fase perkembangan dimana seorang individu akan mengalami berbagai macam perubahan. Ketika menghadapi berbagai perubahan baik dalam aspek fisik, kognitif dan psikososial remaja membutuhkan kehadiran orang tua/dewasa untuk dapat memahami dan memberikan perlakuan yang sesuai dengan kebutuhannya (Tricahyani \& Widiasavitri, 2014). Adanya hubungan yang erat, komunikasi terbuka yang sehat, dan dukungan dari orangtua menjadi sangat penting agar remaja dapat melewati berbagai perubahan dengan baik (Aufseeser, Jekielek, \& Brown, 2006).

Akan tetapi, dalam melewati masa perkembangannya tidak semua remaja bisa mendapatkan pengasuhan dan dukungan dari keluarga atau orang tua. Hal tersebut disebabkan oleh beberapa faktor seperti kehilangan orang tua hingga keterbatasan/kesulitan ekonomi yang membuat mereka harus ditempatkan dilingkungan lembaga sosial seperti panti asuhan. Penempatan tersebut bertujuan untuk dapat memberikan pelayanan pengganti orang tua atau keluarga dan bertanggung jawab dalam memenuhi kebutuhan fisik, mental, dan sosial kepada anak asuh (Depsos RI, dalam Armis, 2016).

Pada kenyataannya tidak semua panti asuhan dapat sepenuhnya memberikan pelayanan, pengasuhan serta lingkungan yang kondusif untuk membantu remaja melewati masa perkembangannya. Hal tersebut terlihat dari data yang didapatkan oleh Komisi Nasional Perlindungan Anak (Komnas PA) yang mencatat bahwa dari sekitar 3000 panti asuhan yang berada di daerah Jabodetabek hanya 38 persen yang dapat dikatakan layak dalam hal pelayanan dan telah memiliki izin ("Ribuan Panti Asuhan Masih Belum Layak dan Ilegal", diakses pada 18 Maret 2018). Menurut UNICEF (2009) masih banyak institusi seperti panti asuhan yang kurang memberikan stimulasi, perhatian secara individual, dan juga hanya memberikan lebih sedikit kesempatan untuk pengembangan emosional dan sosial. Selain itu, juga terdapat kurangnya dukungan sosial selama berada di panti asuhan (Tsuraya, 2017), dan juga terkait jumlah pengasuh yang tidak sebanding dengan jumlah anak di panti asuhan sehingga menyebabkan kurangnya pemberian kasih sayang, perhatian dan bimbingan secara mendalam (Rifai, 2015; Yendork \& Somhlaba, 2014). Kondisi tersebut tentunya dapat menimbulkan berbagai dampak negatif bagi anak panti asuhan.

Menurut Groark, McCall, dan Fish (2011) anak-anak yang tinggal di institusi/panti asuhan biasanya mengalami penundaan pada hampir setiap aspek 
perkembangan fisik, mental, dan sosial-emosional mereka. Beberapa dampak negatif yang dapat muncul ialah depresi yang tinggi (Aisha, 2014; Wuon, Bidjuni \& Kallo, 2016), mudah putus asa, penuh dengan ketakutan dan kecemasan (Hartini, 2001) dan konsep diri yang buruk (Shvets, 2011 dalam Shulga, Savchenko, \& Filinkova, 2016), menarik diri dan sulit untuk menjalin hubungan sosial dengan orang lain serta memiliki masalah sosial di sekolah baik dengan teman maupun guru (Tsuraya, 2017). Oleh karena itu, dapat dikatakan bahwa kondisi lingkungan dan kehidupan remaja panti asuhan kurang kondusif untuk membantu proses perkembangan dan juga dapat memberikan berbagai dampak negatif.

Bagi remaja panti asuhan yang berada dalam lingkungan dan keadaan hidup seperti itu sangat diperlukan untuk memiliki orientasi terkait masa depan yang positif. Hal tersebut karena, memiliki orientasi masa depan positif sangat penting untuk remaja yang berada dalam keadaan kehidupan negatif (Kerpelman, Eryigit, \& Stephens, 2008). Ostaszewski dan Zimmerman, (2006) yang menyatakan bahwa orientasi masa depan dapat menjadi prediktor penting dalam kemampuan remaja untuk mengatasi berbagai kondisi lingkungan yang merugikan. Selain itu, McCabe dan Barnett (2000) mengatakan bahwa orientasi masa depan dapat menjadi faktor pelindung bagi remaja, terutama remaja yang hidup dengan kesulitan ekonomi dan berada dalam anggota kelompok minoritas.

Secara sederhana orientasi masa depan dapat diartikan sebagai gambaran yang dimiliki seseorang tentang masa depan mereka (Seginer, 2008). Steinberg dkk, (2009) menyatakan bahwa orientasi masa depan merupakan suatu cara pandang individu dalam memandang masa depannya yang tergambar melalui pandangan-pandangan, harapan-harapan, minat-minat, motif-motif, dan ketakutan-ketakutan individu terhadap masa depan. Seginer dan Schlesinger (dalam McWhirter \& McWhirter, 2008) mengartikan orientasi masa depan remaja sebagai gambaran yang dikembangkan individu tentang diri mereka di masa depan yang diekspresikan dalam bentuk harapan dan ketakutan.

Menurut Trommsdoroff (2005) orientasi masa depan merupakan fenomena kognitif motivasional yang kompleks, yakni antisipasi dan evaluasi tentang diri di masa depan dalam interaksinya dengan lingkungan. Orientasi masa depan dapat memberikan dasar untuk menetapkan tujuan, merencanakan, mengeksplorasi pilihan dan membuat komitmen yang menuntun perilaku dan perkembangan individu (Bandura, 2001; Seginer, 2008). Orientasi masa depan memungkinkan remaja untuk bermimpi dan mengharapkan kemungkinan yang lebih baik di masa depan, serta mengambil tindakan yang dapat meningkatkan pencapaian tujuan (Kerpelman, Eryigit \& Stephens, 2008). Orientasi masa depan remaja dipandang sebagai prediktor penting dalam pencapaian pada masa dewasa seperti pendidikan (Messersmith \& Schulenberg, 2008). Selain itu, bagaimana remaja melihat masa depan mereka memainkan peran penting dalam pembentukan identitas (Bosma, 1985; Marcia, 1980 dalam Nurmi, 1991).

Pada masa remaja, inti dari orientasi masa depan terdiri atas tiga domain yaitu, pendidikan tinggi, pekerjaan dan karier, serta pernikahan dan keluarga 
EDGART ANDREAN \& SARI ZAKIAH AKMAL, Bagaimana Remaja Panti Asuhan Memandang Masa Depan? Pentingnya Dukungan Lingkungan

(Seginer, 2008). Orientasi masa depan remaja terutama yang berkaitan dengan karier, gaya hidup, dan keluarga di masa depan sangat mempengaruhi kehidupan di masa dewasa nanti (Nurmi, 1991). Pada masa remaja hal utama yang perlu dipertimbangkan ialah masalah pendidikan dan pekerjaan masa depan dibandingkan dengan masalah-masalah yang lainnya (Maslihah, 2011). Dengan kata lain, pada remaja aspek terkait orientasi masa depan akan lebih terfokus pada aspek pendidikan dan pekerjaan. Sehingga dapat dikatakan pada masa remaja tidak terkecuali remaja panti asuhan seharusnya memiliki orientasi masa depan yang positif terkait pendidikan dan pekerjaan. Pada penelitian ini domain prospektif yang akan dilihat ialah domain pendidikan, pekerjaan dan karier. Hal tersebut karena domain yang lebih menjadi pertimbangan dan dipikirkan pada masa remaja ialah masalah pendidikan dan pekerjaan masa depan dibandingkan dengan masalah-masalah yang lainnya (Maslihah, 2011).

Akan tetapi, ditemukan bahwa masih terdapat remaja panti asuhan yang merasa kesulitan untuk membuat perencanaan terkait masa depannya (Yuniana, 2013). Hasil penelitian yang dilakukan Gozali (2011) pada sebuah panti asuhan mendapatkan kesimpulan bahwa sebanyak 66,7\% remaja yang tinggal di panti asuhan tersebut memiliki orientasi masa depan bidang pekerjaan yang tidak jelas. Hal ini tergambar dari para remaja panti asuhan yang tidak memiliki perencanaan terkait pekerjaan secara terarah dan evaluasi perencanaan terkait pekerjaan yang tidak akurat, dan juga adanya sebagian remaja dengan motivasi orientasi masa depan yang rendah (Gozali, 2011). Sedangkan, menurut Nurmi (1991) aspek motivasi, perencanaan dan evaluasi merupakan tiga proses yang dapat menggambarkan perkembangan dalam pembentukan orientasi masa depan.

Terdapat berbagai faktor yang mempengaruhi pembentukan orientasi masa depan terkait pendidikan dan pekerjaan pada masa remaja. Menurut Seginer, (2008) pembentukan orientasi masa depan dihasilkan dari negosiasi antara kebutuhan pribadi dan interpretasi mereka terhadap nilai, realitas sosio-ekonomi dan peluang perkembangan yang diberikan oleh lingkungan remaja. Sejalan dengan itu, Crespo, Jose, Kielpikowski, dan Pryor (2013) menyatakan bahwa keterhubungan remaja dengan keluarga dan lingkungan sekolah memprediksi persepsi positif terhadap orientasi masa depan. Kondisi sosial ekonomi juga dapat membentuk pandangan individu tentang masa depan yang mempengaruhi keputusan serta perencanaan individu kedepannya (Nurmi, 2004 dalam Kolesovs, 2013). Selain itu, etnis/budaya dan gender remaja juga dianggap sebagai faktor yang dapat berdampak pada orientasi masa depan (Green \& DeBacker, 2004).

Bagi remaja panti asuhan, kondisi-kondisi di atas merupakan bagian dari permasalahan yang harus dihadapi oleh mereka. Seperti yang telah dijelaskan sebelumnya remaja yang berada di panti asuhan kurang mendapatkan stimulasi, perhatian secara individual, kasih sayang dan bimbingan secara mendalam dikarenakan jumlah pengasuh yang tidak sebanding dengan jumlah anak di panti asuhan. Selain itu, permasalahan sosial ekonomi juga merupakan salah satu kondisi yang membuat mereka ditempatkan di dalam panti asuhan. Hal tersebut karena, kondisi paling umum yang menyebabkan seseorang menerima perawatan 
di panti asuhan ialah adanya ketidakmampuan ekonomi atau sosial hingga kurangnya perawatan dari keluarga (Dunovský, Dytrych, \& Matějček; Young \& Richardson, dalam Holický, Kokštejn, \& Musálek, 2015).

Aspek-aspek yang terkait dengan pembentukan orientasi masa depan seperti etnis, gender, status sosial ekonomi, teman, keluarga dan lingkungan sosial merupakan aspek yang termasuk kedalam konsep contextual support and barrier (Lent, Hackett \& Brown, 2000). Menurut Social Cognitive Career Theory (SCCT) faktor kontekstual merupakan salah satu faktor yang dapat memperngaruhi pengembangan karier seseorang melalui pembentukan minat karier, pengembangan tujuan, dan kinerja (Lent dkk., 2000). Teori ini mengidentifikasi interaksi antara atribut pribadi, faktor lingkungan eksternal, dan perilaku dalam proses pengambilan keputusan karier (Kerka, 1998).

Contextual support and barrier dapat didefinisikan sebagai dukungan dan hambatan sosial (Lent dkk., 2005). Lent dkk. (2000) mendefinisikan contextual support and barrier sebagai variabel dari luar diri individu yang dapat meningkatkan atau menghambat kemajuan dalam karier. Contextual support dapat memfasilitasi dan membantu pembentukan dan pengejaran terkait karier, sedangkan contextual barrier merupakan batasan atau hambatan. Contextual support dan barrier dapat dinyatakan dalam bentuk sesuatu yang terlihat dan terdata (misalnya, pendapatan orang tua) ataupun aspek yang dirasakan dari lingkungan (misalnya, ketersediaan model peran karier, adanya bias gender) (Lent \& Brown, 2006).

Dukungan dan hambatan yang didapatkan remaja dapat membantu bagaimana remaja menentukan arah terkait pendidikan dan pekerjaan di masa depan terutama dalam hal perencanaan dan tindakan. Hasil penelitian McWhirter, Hackett, dan Bandalos (1998) menunjukan bahwa dukungan dari ayah yang dirasakan remaja perempuan ditemukan berkaitan dengan rencana pendidikan dan ekspektasi terkait karier di masa depan. Selain itu, pengetahuan tentang diri dan pengalaman masa lalu serta dukungan yang diberikan oleh orang-orang sekitar diidentifikasi dapat memberikan pengaruh pada perencanaan karier masa depan pada remaja (Howard, dkk, 2010). Jika seseorang merasakan adanya hambatan dalam proses meraih keberhasilannya maka dapat menyebabkan penurunan pada minat (Lent dkk, 2000). Sebaliknya, jika lingkungan umumnya mendukung, individu lebih mungkin untuk melihat masa depan secara positif karena mereka tahu bahwa mereka dapat bergantung pada orang tua dan guru untuk memberi bimbingan dan bantuan pada saat dibutuhkan (Urbig \& Monsen, 2012).

Dari pemaparan di atas, dapat dikatakan bahwa dukungan dan hambatan yang didapatkan oleh remaja dapat mempengaruhi bagaimana remaja membuat perencanaan terkait pendidikan dan karier masa depannya. Menyusun perencanaan masa depan merupakan salah satu dasar dari terbentuknya orientasi masa depan, dimana individu mulai merencanakan realisasi dari tujuan dan minat mereka. Sehingga penelitian ini penting dilakukan pada remaja terutama remaja panti asuhan untuk melihat bagaimana dukungan dan hambatan yang ada dalam lingkungan remaja panti asuhan dapat membentuk orientasi masa depannya. Hal 
EDGART ANDREAN \& SARI ZAKIAH AKMAL, Bagaimana Remaja Panti Asuhan Memandang Masa Depan? Pentingnya Dukungan Lingkungan

tersebut mengingat pentingnya memiliki orientasi masa depan positif bagi remaja panti asuhan untuk menghadapi lingkungan dan kehidupan yang negatif. Oleh karena itu, penelitian ini dilakukan untuk mengetahui peranan contextual support and barrier terhadap orientasi masa depan terkait pendidikan dan pekerjaan pada remaja panti asuhan.

\section{METODE PENELITIAN}

\section{Identifikasi Variabel}

Variabel penelitian ini adalah:

Variabel Kriterium: Orientasi masadepan terkait pendidikan dan pekerjaan

Orientasi masa depan terkait pendidikan dan pekerjaan merupakan gambaran individu terhadap dirinya dalam konteks pendidikan dan pekerjaan di masa depan yang menjadi dasar untuk menetapkan tujuan, rencana, dan evaluasi sejauh mana tujuan tersebut dapat terealisasi yang diekspresikan dalam bentuk harapan dan ketakutan.

\section{Variabel Prediktor: Contextual support dan barrier}

Contextual support and barrier dapat diartikan sebagai variabel dari luar diri individu yang dapat memfasilitasi, meningkatkan ataupun menghambat kemajuan dalam proses penetapan minat, tujuan pada karier.

\section{Subjek Penelitian}

Penelitian ini menggunakan populasi dalam remaja panti asuhan yang tinggal menetap di panti asuhan dengan rentang usia 11-18 tahun di Jakarta dan Bekasi dengan subjek penelitian berjumlah 105 subjek. Partisipan direkrut dengan menggunakan teknik sampel insidental.

\section{Metode Pengambilan Data}

Variabel orientasi masa depan diukur dengan menggunakan alat ukur Future Expectations Scale for Adolescents (FESA) dari McWhirter dan McWhirter (2008). Skala ini terdiri dari 5 subskala yaitu, work and education, marriage and family, church and community, health, dan children's future (McWhirter \& McWhirter, 2008). Pada penelitian ini hanya menggunakan subskala work and education yang diadaptasi dalam Bahasa Indonesia. Subskala tersebut terdiri dari 10 aitem terkait dengan pekerjaan dan pendidikan. Untuk subskala work and education memiliki konsistensi internal sebesar $\alpha=0,88$ (McWhirter \& McWhirter, 2008).

Variabel contextual support and barrier diukur menggunakan skala Contextual Support and Barrier yang dibuat oleh Lent, Brown, dan Hackett (2003). Alat ukur tersebut terdiri dari 2 dimensi yaitu support 15 item dan barrier 23 item dengan total 38 item. Berdasarkan studi yang dilakukan oleh Pratiwi dan Akmal (2018) didapatkan koefisien reliabilitas pada dimensi contextual support sebesar 0,876. Sedangkan, koefisien reliabilitas pada dimensi contextual barrier sebesar 0,939 . 


\section{Teknik Analisis Data}

Penelitian ini bertujuan untuk melihat teknik analisis data penelitian yang digunakan didalam penelitian ini ialah teknik analisis regresi sederhana, dimana sebelum melakukan uji regresi sederhana, peneliti melakukan uji normalitas data dan uji linearitas. Berdasarkan hasil dari uji normalitas melalui perhitungan nilai residual menunjukkan nilai residual berdistribusi normal $(\mathrm{p}>0,05)$. Berdasarkan hasil uji linearitas diketahui bahwa variabel contextual pada dimensi support memiliki hubungan yang linear dengan variabel orientasi masa depan $(\mathrm{F}$ 9,522 $\mathrm{p}$ $<0,05)$. Namun, pada dimensi barrier memiliki hasil yang tidak linear dengan variable orientasi masa depan $(\mathrm{F}=0,212, \mathrm{p}>0.05)$. Oleh karena itu, proses analisis data penelitian dengan melakukan uji regresi hanya dapat dilanjutkan pada dimensi support yang telah memenuhi asumsi linearitas data.

\section{HASIL DAN PEMBAHASAN}

Jumlah subjek dalam penelitian ini berjumlah sebanyak 105 remaja panti asuhan di Jakarta dan Bekasi dengan rata-rata usia 14,53 (SD: 1,803). Selanjutnya, peneliti melakukan uji pendahuluan untuk melihat adanya pengaruh dari berbagai faktor demografi yang dapat mempengaruhi variabel penelitian seperti, jenis kelamin dan usia. Peneliti melakukan uji beda pada variabel orientasi masa depan untuk mengetahui perbedaan kelompok berdasarkan faktor demografi jenis kelamin dan usia. Berdasarkan hasil analisa uji beda pada tabel 1 dapat dikatakan bahwa faktor demografi usia $(\mathrm{t}=-0,318, \mathrm{p}>0,05)$ dan jenis kelamin $(\mathrm{t}=-0,527, \mathrm{p}>0,05)$ tidak menyebabkan perbedaan yang signifikan pada orientasi masa depan terkait pendidikan dan pekerjaan.

Tabel 1. Uji Beda Orientasi Masa Depan Berdasarkan Jenis Kelamin \&Usia

\begin{tabular}{llccc}
\hline & Data & Mean & T & Sig \\
\hline Jenis kelamin & Perempuan & 57,3 & $-0,527$ & 0,600 \\
Usia & Laki-laki & 56 & & \\
& $\begin{array}{l}\text { Remaja Awal }(11- \\
\text { 15) } \\
\text { Remaja Akhir (16 - }\end{array}$ & 56,7 & & 0,751 \\
& $18)$
\end{tabular}

Tabel 2. Uji Regresi

\begin{tabular}{ccccc}
\hline Dimensi & R-Square & F & Sig. & Persamaan Regresi \\
\hline Support & 0,087 & 9,767 & 0,002 & $\mathrm{Y}=36,583+0,116 \mathrm{X}$ \\
\hline
\end{tabular}

Berdasarkan tabel 2 ditemukan bahwa contextual support berperan secara signifikan terhadap orientasi masa depan terkait pendidikan dan pekerjaan pada remaja panti asuhan $(\mathrm{R} 2=0.087, \mathrm{~F}=9,767, \mathrm{p}<0.05)$. Hal ini berarti contextual support berperan terhadap orientasi masa depan terkait pendidikan dan pekerjaan sebesar $8,7 \%$ dan $91,3 \%$ lainnya dipengaruhi oleh faktor lain. Selain itu, berdasarkan uji regresi ditemukan nilai konstanta sebesar 36,583 dan nilai koefisien regresi $\mathrm{X}$ sebesar 0,116 . Hal tersebut menunjukkan bahwa tiap 
EDGART ANDREAN \& SARI ZAKIAH AKMAL, Bagaimana Remaja Panti Asuhan Memandang Masa Depan? Pentingnya Dukungan Lingkungan

penambahan 1 nilai pada contextual support, maka akan mengakibatkan nilai orientasi masa depan terkait pendidikan dan pekerjaan bertambah sebesar 0,116.

Berdasarkan hasil penelitian ditemukan bahwa, contextual support yang dirasakan oleh remaja panti asuhan berperan secara signifikan terhadap orientasi masa depan pada domain pendidikan dan pekerjaan $(\mathrm{F}=9,676 \mathrm{p}<0.05)$. Hasil tersebut menunjukan bahwa contextual support memiliki peranan sebesar $8,7 \%$ terhadap orientasi masa depan pada domain pendidikan dan pekerjaan, dan 91,3\% lainnya dipengaruhi oleh faktor lain. Hal tersebut menunjukan bahwa dukungan yang dirasakan oleh remaja panti asuhan dari lingkungan dapat mempengaruhi orientasi masa depan pada domain pendidikan dan pekerjaan. Hasil tersebut sejalan dengan penelitian dari McWhirter dkk (1998), menunjukan bahwa dukungan (support) yang dirasakan dari orang tua serta guru membuat seorang remaja memiliki tingkat ekspektasi dan rencana terkait pendidikan serta kejuruan yang lebih tinggi.

Contextual support terdiri dari beberapa aspek seperti keluarga, teman, status sosial-ekonomi, gender, ras dan budaya, serta institusi pendidikan (Lent, dkk 2000). Berbagai hasil penelitian menunjukan bahwa aspirasi dan ekspektasi terkait pendidikan dan pekerjaan juga dapat dipengaruhi oleh berbagai aspek lingkungan atau eksternal, seperti gender (Wahl \& Blackhurst, 2000), ras, status sosial-ekonomi (Hellenga, Aber, \& Rhodes, 2002), dukungan sosial (Wall, Covell, \& MacIntyre, 1999), serta gaya pengasuhan (Steinberg, Lamborn, Dornbusch, \& Darling, 1992).

Pada aspek keluarga, persepsi remaja tentang interaksi yang hangat, mendukung, dan dapat diandalkan antara mereka dan orang tua dapat memberikan model perilaku positif yang kemudian dimasukkan ke dalam konsep diri dan kemudian akan mengarahkan harapan mereka kepada masa depan (McCabe \& Barnett, 2000). Sejalan dengan itu, Iovu, Hărăguș, \& Roth (2018) mengatakan bahwa pengembangan ekspektasi/harapan masa depan seseorang secara dinamis dipengaruhi oleh hubungannya dengan orang lain yang signifikan (misalnya, anggota keluarga atau teman). Pada remaja panti asuhan, pengasuh merupakan sosok signifikan yang memiliki tugas dan tanggungjawab sebagai pengganti orangtua. Sehingga, dapat dikatakan pada remaja panti asuhan bentuk pengasuhan dan interaksi yang hangat serta mendukung dari pengasuh dapat menjadi support bagi mereka dalam mengarahkan dan membentuk harapan mereka terkait masa depan terutama pada pendidikan dan pekerjaan.

Pada aspek teman sebaya, dukungan yang didapatkan dari teman sebaya juga terbukti berkontribusi terhadap pembentukan ekspektasi remaja terkait masa depan (Harter, Marold \& Whitesell, 1996). Menurut Mazibuko dan Tlale (2014) jenis teman sebaya yang dimiliki seorang remaja, akan menentukan sifat orientasi masa depan bagi mereka. Dengan kata lain jika orientasi masa depan dalam kelompok pertemanan tersebut bersifat terperinci, optimis, dan terarah, maka remaja tersebut juga akan memiliki pandangan optimis tentang masa depannya. Hal tersebut juga berlaku bagi remaja panti asuhan yang tinggal dan berinteraksi 
dengan teman sebaya baik di dalam panti asuhan maupun dengan teman di sekolah. Dengan demikian, dapat dikatakan bahwa dengan adanya dukungan dari teman sebaya yang optimis dan terarah akan berdampak pada terbentuknya orientasi masa depan terkait pendidikan dan pekerjaan yang optimis.

Pada aspek status sosial-ekonomi, terdapat berbagai penelitian yang menunjukan bahwa orang-orang dari status sosial-ekonomi yang tinggi lebih mungkin untuk berorientasi kepada masa depan (Corral-Verdugo, Fraijo-Sing, \& Pinheiro, 2006; D'Alessio, Guarino, DePascalis, \& Zimbardo, 2003; Epel, Bandura, \& Zimbardo, 1999). Namun, pada remaja panti asuhan, permasalahan ekonomi merupakan alasan dari penempatan mereka ke dalam panti asuhan, sehingga dapat dikatakan bahwa remaja panti asuhan mayoritas berada dalam kondisi sosial-ekonomi yang rendah dan hal tersebut dapat menjadi hambatan/barrier bagi mereka. Ketika remaja mendapatkan hambatan dalam aspek kemiskinan dan diskriminasi ras/etnis, akan berdampak pada proses pengembangan pendidikan dan karier remaja dengan cara mengurangi aspirasi dan harapan terkait karier serta mengurangi motivasi untuk bersekolah dan menggapai kesuksesan dalam karier (Constantine, Erickson, Banks \& Timberlake, 1998).

Hasil penelitian menunjukan bahwa, contextual barrier tidak berkorelasi dengan orientasi masa depan terkait pendidikan dan pekerjaan pada remaja panti asuhan. Hasil tersebut menunjukan bahwa baik-buruknya orientasi masa depan terkait pendidikan dan pekerjaan pada remaja panti asuhan tidak disebabkan oleh adanya barrier yang dirasakan oleh mereka. Hasil tersebut tidak sejalan dengan pernyataan Kenny, Blustein, Chaves, Grossman, dan Gallagher, (2003) bahwa hambatan (barrier) yang dirasakan terkait karier dan kesuksesan dapat menjadi salah satu faktor yang mengarahkan remaja untuk membentuk perilaku merugikan seperti, melepaskan diri dari tugas pengembangan akademik dan karier mereka.

Hasil diatas dapat dikatakan terjadi karena remaja panti asuhan mendapatkan dan merasakan adanya dukungan yang tinggi dari lingkungannya. Hal tersebut karena, hambatan (barrier) yang dirasakan oleh remaja panti asuhan sebelum berada di dalam panti asuhan (distal contextual) seperti kondisi ekonomi yang buruk, tidak adanya sosok orangtua dan sebagainya menjadi tergantikan oleh besarnya dukungan yang mereka peroleh ketika berada di dalam panti asuhan. Sehingga penempatan ke dalam panti asuhan membuat mereka merasa mendapatkan harapan dan bantuan untuk dapat meneruskan pendidikan dan karier mereka.

Dari hasil yang didapatkan pada penelitian ini dapat dikatakan bahwa remaja panti asuhan yang berada dalam lingkungan dan kondisi hidup negatif mengembangkan dan membentuk orientasi masa depan yang positif melalui dukungan yang diberikan dari lingkungan. Sejalan dengan itu, Schmidt, Pierce, dan Stoddard (2016) menyatakan bahwa hubungan sosial yang kuat dapat meningkatkan persepsi remaja tentang masa depan yang positif. Selain itu, menurut Urbig \& Monsen (2012) lingkungan yang umumnya mendukung dapat 
EDGART ANDREAN \& SARI ZAKIAH AKMAL, Bagaimana Remaja Panti Asuhan Memandang Masa Depan? Pentingnya Dukungan Lingkungan

membuat seseorang untuk melihat masa depan secara positif karena mereka tahu bahwa mereka dapat bergantung orang-orang disekitar mereka untuk memberi bimbingan dan bantuan pada saat dibutuhkan. Hasil tersebut dapat menjadi pertimbangan bagi penelitian selanjutnya kepada remaja lain yang juga berada dalam kondisi lingkungan dan kehidupan negatif mengingat orientasi masa depan yang positif dapat menjadi faktor pelindung bagi remaja yang tinggal dalam lingkungan yang merugikan.

Pada penelitian ini ditemukan bahwa 91,3\% variabel orientasi masa depan terkait pendidikan dan pekerjaan dipengaruhi oleh faktor lain yang tidak menjadi bagian dari penelitian ini. Hasil tersebut menunjukkan bahwa perkembangan orientasi masa depan yang positif pada remaja panti asuhan sebagian besar dapat dipengaruhi oleh berbagai faktor lain diluar faktor kontektual. Dalam proses perkembangan orientasi masa depan seorang individu terdapat beberapa hal yang dapat dipertimbangkan salah satunya faktor psikologis, seperti perkembangan kognitif, sosial (Nurmi, 1991), serta interpersonal seperti self efficacy (Judge \& Bono, 2001; Luzzo \& McWhirter, 2001), self-esteem (Aisyah, 2015), kesepian (Seginer \& Lilach, 2004) dan religiusitas (Marliani, 2013).

Penelitian ini memiliki kekurangan yang dapat dijadikan pertimbangan untuk melakukan penelitian di masa mendatang. Dalam penelitian ini peneliti hanya menilai orientasi masa depan dalam ranah motivasional yaitu terkait dengan harapan/ekspektasi individu terhadap masa depannya, sehingga gambaran yang didapatkan terkait orientasi masa depan masih terbatas. Hal tersebut karena, orientasi masa depan dapat memberikan dasar untuk menetapkan tujuan, merencanakan, mengeksplorasi pilihan dan membuat komitmen yang menuntun perilaku dan perkembangan individu (Bandura, 2001; Seginer, 2008).

\section{KESIMPULAN}

Hasil dari penelitian ini menunjukkan bahwa contextual support yang dirasakan oleh remaja panti asuhan secara signifikan berperan terhadap orientasi masa depan terkait pendidikan dan pekerjaan.

Hasil penelitian ini menekankan pada pentingnya dukungan yang diberikan oleh lingkungan sekitar dalam membantu remaja panti asuhan meningkatkan orientasi masa depannya. Oleh karena itu, perlu dilakukan serangkaian kegiatan pemberian informasi kepada pengelola panti asuhan, dinas sosial dan petugas panti mengenai pentingnya dukungan lingkungan bagi perkembangan remaja.

Penelitian ini juga dapat memberikan beberapa saran pengembangan seperti dengan melakukan penelitian lanjutan yang juga melihat peranan faktor lain seperti self-esteem, self-efficacy dan faktor personal lainnya yang dapat mempengaruhi pembentukan orientasi masa depan remaja di panti asuhan. Penelitian yang spesifik untuk mengidentifikasi sumber dukungan sosial yang paling penting bagi remaja panti asuhan, juga perlu dilakukan. Penelitian 
selanjutnya juga dapat melakukan pengembangan penelitian denganmelihat konsep orientasi masa depan secara keseluruhan baik dalam aspek motivasional, perencanaan dan evaluasi, sehingga mendapatkan gambaran yang lebih komprehensif terhadap orientasi masa depan.Selain itu, penelitian serupa juga dapat dilakukan untuk meneliti kelompok remaja rentan lainnya seperti remaja penyandang disabilitas, anak jalanan, dan sebagainya.

\section{DAFTAR PUSTAKA}

Aisha, D. L. (2014). Hubungan Antara Religiusitas Dengan Resiliensi Pada Remaja Di Panti Asuhan Keluarga Yatim Muhammadiyah Surakarta. Skripsi. Surakarta: Fakultas Psikologi Universitas Muhammadiyah Surakarta.

Aisyah, S. (2015). Hubungan self esteem dengan orientasi masa depan pada siswa SMA kelas XI di SMA Negeri 3 Malang. Skripsi. Malang: Universitas Islam Negeri Maulana Malik Ibrahim.

Armis, A. (2016). Manajemen Panti Asuhan At-Taqwa Muhammadiyah dalam Membina Kepribadian Siswa MTS Muhammadiyah Padang Luar Kecamatan Rambatan Kabupaten Tanah Datar. Al-Fikrah, 3(2), 137-146.

Aufseeser, D., Brown, B., \& Jekielek, S. (2006). The Family Environment and Adolescent Well-Being: Exposure to Positive and Negative Family Influences. Child Trends and the National Adolescent Health Information Center.

Bandura, A. (2001). Social cognitive theory: An argentic perspective, Annual Review of Psychology, 52, 1-26.

Constantine, M. G., Erickson, C. D., Banks, R. W., \& Timberlake, T. L. (1998). Challenges to the career development of urban racial and ethnic minority youth: Implications for vocational intervention. Journal of Multicultural Counseling and Development, 26(2), 83-95.

Corral-Verdugo, V., Fraijo-Sing, B., \& Pinheiro, J. Q. (2006). Sustainable behavior and time perspective: Present, past, and future orientations and their relationship with water conservation behavior. Interamerican Journal of Psychology, 40(2).

Crespo, C., Jose, P. e., Kielpikowski, M., \& Pryor, J. (2013). "On solid ground": family and school connectedness promotes adolescents' future orientation. Journal of Adolescence, 36, 993-1002

Epel, E. S., Bandura, A., \& Zimbardo, P. G. (1999). Escaping homelessness: The influences of self-efficacy and time perspective on coping with homelessness. Journal of Applied Social Psychology, 29(3), 575-596. 
EDGART ANDREAN \& SARI ZAKIAH AKMAL, Bagaimana Remaja Panti Asuhan Memandang Masa Depan? Pentingnya Dukungan Lingkungan

Gozali, Y. (2011). Studi Deskriptif Mengenai Orientasi Masa Depan Bidang Pendidikan Pada Remaja Panti Asuhan Putra "X" Di Kota Bandung. Skripsi. Bandung: Universitas Kristen Maranatha.

Groark, C. J., McCall, R. B., Fish, L., \& Whole Child International Evaluation Team. (2011). Characteristics of environments, caregivers, and children in three Central American orphanages. Infant Mental Health Journal, 32(2), 232-250.

Harter, S., Marold, D. B., Whitesell, N. R., \& Cobbs, G. (1996). A model of the effects of perceived parent and peer support on adolescent false self behavior. Child development, 67(2), 360-374.

Hartini, N. (2001). Deskripsi Kebutuhan Psikologis Pada Anak Panti Asuhan. Jurnal Insan Media Psikologi, 3(2) 99-108

Hellenga, K., Aber, M. S., \& Rhodes, J. E. (2002). African American adolescent mothers' vocational aspiration-expectation gap: Individual, social and environmental influences. Psychology of women quarterly, 26(3), 200-212.

Holický, J., Kokštejn, J., \& Musálek, M. (2015). Psychomotor development differences between Czech adolescents from orphanages and adolescents from majority society. Acta Gymnica, 45(3), 147-154.

Howard, K. A. S., Budge, S. L., Gutierrez, B., Owen, A. D., Lemke, N., Jones, J. E., \& Higgins, K. (2010). Future plans of urban youth: Influences, perceived barriers, and coping strategies. Journal of Career Development, 37, 655-676.

Iovu, M. B., Hărăguș, P. T., \& Roth, M. (2018). Constructing future expectations in adolescence: relation to individual characteristics and ecological assets in family and friends. International Journal of Adolescence and Youth, 23(1), 1-10.

Judge, T. A., \& Bono, J. E. (2001). Relationship of core self-evaluations traitsself-esteem, generalized self-efficacy, locus of control, and emotional stability-with job satisfaction and job performance: A meta-analysis. Journal of Applied Psychology, 86(1), 80.

Kenny, M. E., Blustein, D. L., Chaves, A., Grossman, J. M., \& Gallagher, L. A. (2003). The role of perceived barriers and relational support in the educational and vocational lives of urban high school students. Journal of Counseling Psychology, 50(2), 142.

Kerka, S. (1998). Career Development and Gender, Race, and Class. ERIC Digest No. 199. 
Kerpelman. J., Eryigit. S., \& Stephens C. J. (2008). African American Adolescents' Future Education Orientation: Associations with Selfefficacy, Ethnic Identity, and Perceived Parental Support. Journal of Youth and Adolescence, 37(8):997-1008

Kolesovs, A. (2013). Domain-specific and general future orientation of high school students in Latvia under socioeconomic changes. International journal of psychology: a biopsychosocial approach, 12, 71-83.

Lent, R.W., Brown, S.D., \& Hackett, G. (2000). Contextual supports and barriers to career choice: A social cognitive analysis. Journal of Counseling Psychology, 47, 36- 49.

Lent, R. W., Brown, S. D., Schmidt, J., Brenner, B., Lyons, H., \& Treistman, D. (2003). Relation of contextual supports and barriers to choice behavior in engineering majors: Test of alternative social cognitive models. Journal of Counseling Psychology, 50(4), 458.

Lent, R. W., \& Brown, S. D. (2006). On conceptualizing and assessing social cognitive constructs in career research: A measurement guide. Journal of career assessment, 14(1), 12-35.

Luzzo, D. A., \& McWhirter, E. H. (2001). Sex and ethnic differences in the perception of educational and career- related barriers and levels of coping efficacy. Journal of Counseling \& Development, 79(1), 61-67.

Marliani, R. (2013). Hubungan Antara Religiusitas Dengan Orientasi Masa Depan Bidang Pekerjaan Pada Mahasiswa Tingkat Akhir. Jurnal Psikologi, 9(2), 130-137.

Maslihah, S. (2011). Studi Tentang Hubungan Dukungan Sosial, Penyesuaian Diri di Lingkungan Sekolah dan Prestasi Akademik Siswa SMPIT Assyfa Boarding School Subang Jawa Barat. Jurnal Psikologi Undip, 10(2).

McCabe, K., \& Barnett, D. (2000). The relations between familial factors and the future orientation of urban, African American sixth graders. The Journal of Child and Family Studies, 9(4), 491-508.

McWhirter, E. H., Hackett, G., \& Bandalos, D. L. (1998). A causal model of the educational plans and career expectations of Mexican American high school girls. Journal of Counseling Psychology, 45, 166-181.

McWhirter, E. H., \& McWhirter, B. T. (2008). Adolescent future expectations of work, education, family, and community development of a new measure. Youth \& Society, 40(2), 182-202.

Mazibuko, M. E., \& Tlale, D. N. (2014). Factors that Shape the Adolescent's Future Orientation: Analysing Qualitative Data. Mediterranean Journal of Social Sciences, 5(2), 237. 
EDGART ANDREAN \& SARI ZAKIAH AKMAL, Bagaimana Remaja Panti Asuhan Memandang Masa Depan? Pentingnya Dukungan Lingkungan

Messersmith, E. E., \& Schulenberg, J. E. (2008). When can we expect the unexpected? Predicting educational attainment when it differs from previous expectations. Journal of Social Issues, 64(1), 195-211

Nurmi, J. E. (1991). How Do Adolescents See Their Future? A Review of the Development of Future Orientation and Planning. Developmental Review, $11,1-59$.

Ostaszewski. K \& Zimmerman M. A. (2006). The Effects of Cumulative Risks and Promotive Factors on Urban Adolescent Alcohol and Other Drug Use: A Longitudinal Study of Resiliency. American Journal of Community Psychology, 38, 3-4.

Pratiwi, D. I., \& Akmal, S. Z. (2018). Peran contextual support and barrier terhadap career indecision pada mahasiswa tingkat akhir. Jurnal Ilmiah Psikologi Terapan, 6(2), 194-206.

Rifai, N. (2015). Penyesuaian Diri Pada Remaja yang Tinggal Di Panti Asuhan (Study Kasus Pada Remaja yang Tinggal Di Panti Asuhan Yatim Piatu Muhammadiyah Klaten). Skripsi. Surakarta: Fakultas Psikologi Universitas Muhammadiyah Surakarta.

Schmidt, C. J., Pierce, J., \& Stoddard, S. A. (2016). The mediating effect of future expectations on the relationship between neighborhood context and adolescent bullying perpetration. Journal of Community Psychology, 44(2), 232-248.

Seginer, R. (2008). Future orientation in times of threat and challenge: How resilient adolescents construct their future. International Journal of Behavioral Development, 32(4),272-282

Seginer, R., \& Lilach, E. (2004). How adolescents construct their future: the effect of loneliness on future orientation. Journal of Adolescence, 27(6), 625643.

Seginer, R \& Noyman, M, S. (2005). Future orientation, identity and intimacy: Their relations in emerging adulthood. European Journal of Developmental Psychology, 2 (1), 17-37

Shulga, T. I., Savchenko, D. D., \& Filinkova, E. B. (2016). Psychological Characteristics of Adolescents Orphans with Different Experience of Living in a Family. International Journal of Environmental and Science Education, 11(17), 10493-10504.

Steinberg, L., Lamborn, S. D., Dornbusch, S. M., \& Darling, N. (1992). Impact of parenting practices on adolescent achievement: Authoritative parenting, school involvement, and encouragement to succeed. Child development, 63(5), 1266-1281. 
Steinberg, L., O’Brien, L., Cauffman, E., Graham, S., Wooland. J., \& Banich, M. (2009). Age differences in future orientation and delay discounting. Child Development, 80, 28-44.

Tricahyani, I. A. R., \& Widiasavitri, P. N. (2016). Hubungan antara dukungan sosial dengan penyesuaian diri pada remaja awal di panti asuhan Kota Denpasar. Jurnal Psikologi Udayana, 3(3), 542-550.

Trommsdoroff. G. (2005). An Analysis of Future Orientation and Some of Its Social Determinants. International Journal of Psychology, 5(2).

Tsuraya, F. H. (2017). Hubungan Antara Resiliensi Dengan Subjective WellBeing Pada Remaja Panti Asuhan Di Kabupaten Banyumas. (Skripsi). Puwokerto: Fakultas Psikologi Universitas Muhammadiyah Purwokerto.

UNICEF. (2009). Promoting quality education for orphans and vulnerable children: A sourcebook of programme experiences in Eastern and Southern Africa. New York: UNICEF, 2012.

Urbig, D., \& Monsen, E. (2012). The structure of optimism: Controllability affects the extent to which efficacy beliefs shape outcome expectancies. Journal of Economic Psychology, 33, 854-867.

Wahl, K. H., \& Blackhurst, A. (2000). Factors affecting the occupational and educational aspirations of children and adolescents. Professional School Counseling, 3(5), 367.

Wall, J., Covell, K., \& Macintyre, P. D. (1999). Implications of social supports for adolescents' education and career aspirations. Canadian Journal of Behavioural Science/Revue canadienne des sciences du comportement, 31(2), 63.

Wuon, A. S., Bidjuni, H., \& Kallo, V. (2016). Perbedaan tingkat depresi pada remaja yang tinggal di rumah dan yang tinggal di panti asuhan bakti mulia karombasan kecamatan wanea manado. Jurnal Keperawatan, 4(2).

Yendork, S, J., \& Somhlaba, N. Z. (2015). Do social support, self-efficacy and resilience influence the experience of stress in Ghanaian orphans? An exploratory study. Child Care in Practice, 21(2), 140-159.

Yuniana. 2013. Kesejahteraan Subjektif Pada Yatim Piatu (Mustadh'afin). Jurnal Psikologi, 1, (1), 1-11. 